\title{
Needs Analysis for Developing A Thinking-Based Learning Module In Mathematics Learning
}

\author{
Ruslina Othman ${ }^{1 *}$, Nor'ain Mohd Tajudin ${ }^{2}$, Mazlini Adnan ${ }^{3}$ \\ 1*Sekolah Agama Menengah Paya Jaras, Sungai Buloh, Selangor \\ ${ }^{2,3}$ Department of Mathematics, Faculty of Science and Mathematics, Universiti Pendidikan Sultan Idris, \\ Tanjong Malim, Perak, Malaysia
}

*Corresponding author: ruslinaothman02@gmail.com

Article History:Received:11 January 2021; Accepted: 27 February 2021; Published online: 5 April 2021

\begin{abstract}
It is widely recognized that the application of thinking skills in the teaching and learning of Mathematics has become an important need in the Malaysian context. The level of mathematics teachers understanding on the importance of thinking skills is, therefore, a matter of concern. This need analysis study aims to identify the extent to which thinking skills training has been accepted by Malaysian mathematics teachers and to identify the topics in Form One Mathematics which requires thinking skills infusion. This study used an online questionnaire (Google Forms) of Need Analysis Survey involving 52 respondents among mathematics teachers nationwide. Data are analysed using the descriptive statistics. The finding of the study revealed that although almost $3 / 4$ of them have attended Higher Order Thinking skills (HOTS) courses, yet half of them are still unclear about conducting HOTS teaching. Furthermore, they are not provided with a module to guide HOTS in teaching. This study also found that the topic of Algebraic Expression achieved the highest score as the topic of choice for teachers, which indicated that TS should be infused in this topic during the development of the module. It was concluded that there is a need to develop a thinking-based learning module for Algebraic Expression topic which would enhance the quality of thinking among students in order to enable them to compete globally.
\end{abstract}

Keywords: Thinking Skills, Algebraic Expression, Thinking-Based Learning, Higher Order Thinking Skills.

\section{INTRODUCTION}

The development of the 21 st century demands that everyone has various skills in preparation to equip themselves in facing the development of the era of globalization and innovation (Ballakrishnan \& Maslawati, 2020; Yue Lin, 2018). Among the skills required are critical thinking and problem solving skills, information and communication technology literacy skills as well as contextual learning skills. These skills need to be trained in students as early as possible at the school level and placed as the main objective in learning (Saputri, Sajidan, Rinanto, Afandi \& Prasetyani, 2019). Priority to thinking skills is not a new thing in the education system in Malaysia (Abdul Rashid, 2016). According to (Mintzes \& Walter, 2020) in order to cultivate HOTS in students, teachers need to provide a comfortable environment for students such as sharing ideas, inventions and activities in groups. Among the teaching and learning methods that can enhance the mastery of thinking skills and enable students to be actively involved is through integrating thinking skills in the content of the subject (Swartz \& McGuinness, 2014).

One of the approaches to teaching and learning based on HOTS that is actively and taught in an integrated manner into the content of the subject is the approach of Thinking-Based Learning (PBP) or Thinking-Based Learning. PBP is a teaching approach by integrating habits of mind and metacognition in the content of teaching as a whole (Swartz \& McGuinness, 2014). Simultaneous teaching incorporates the habit of thinking and metacognition called Skilful Thinking (ST). The term ST was introduced by (Swartz \& Parks, 1994) as a methodology in the teaching of thinking skills.

\section{BACKGORUND STUDY}

The background of the study describes the aspects that give an overview of the study to be conducted (Ghazali \&, Sufean, 2018). Officially the Old Secondary School Curriculum (KLSM) started in 1955 (Nik Azis, 2016). KLSM which was founded after independence focuses more on knowledge and examinations as opposed to the emphasis on values and skills to students (Nik Azis, 2016). Activities that actively involve students are very limited, conceptualized by rote teaching, emphasizing higher mathematical knowledge and much teacher centered. KLSM only aims at learning alone (Nik Azis, 2016). As a result, teaching and learning practices do not emphasize thinking skills resulting in limited creative and critical thinking among students (Rajendran, 2017). In short, during KLSM thinking skills are given less attention in the curriculum 


\section{PROBLEM STATEMENT}

Many studies have found that Malaysian students have not yet mastered the HOTS highlighted in the Revised Bloom Taxonomy (MOE, 2019). It is common knowledge that the achievement of Malaysian students in international assessments, namely TIMSS and PISA, is unsatisfactory. Based on the results of PISA 2018, although student achievement increased from 2009 - 2018 but only 54\% achieved level two proficiency compared to the international average of $76 \%$ (The Organization for Economic Co -operation and Development (OECD), 2018). The achievement of Malaysian students is only at the level of knowledge, identifying and interpreting simple mathematics compared to the achievement of Singaporeans who have achieved Level 4 in Mathematical Literacy and Level 3 in Reading Literacy and Scientific Literacy (OECD, 2019). Although the PISA 2018 report shows an improvement in Malaysia's position, but if you look at the performance, the achievement of Malaysian students is still far behind (OECD, 2019).

Apart from PISA, TIMSS is an international assessment specialized in science and mathematics subjects also participated by Malaysia. This difficulty in learning algebra is not only experienced by students in Malaysia, but around the world. The importance of the field of algebra has placed TIMSS paying attention to the content of the algebraic domain in addition to numbers, geometry, data and probability (Mullis, Michael, Pierre, Dana \& Bethany, 2019). However, the achievement of algebra mastery is still below the international benchmark at a moderate level as shown in Table 1. In addition, Table 1.4 shows the differences in Malaysia's achievement far behind Singapore and other Asian countries such as China and South Korea in the content and domain. cognitive.

Table 1. Comparison of Achievement of Malaysian Students in Mathematical Content Domain and Cognitive Domain in TIMSS 2019

\begin{tabular}{|c|c|c|c|c|c|c|c|}
\hline \multicolumn{4}{|c|}{ Content Domain } & \multicolumn{4}{|c|}{ Cognitive Domain } \\
\hline Country & Numbers & Algebra & Geometri & $\begin{array}{l}\text { Data \& } \\
\text { Probability }\end{array}$ & Knowledge & Aplication & Reasoning \\
\hline Singapore & 611 & 619 & 619 & 620 & 614 & 614 & 620 \\
\hline China & 613 & 618 & 623 & 593 & 616 & 610 & 616 \\
\hline $\begin{array}{l}\text { Korea } \\
\text { Selatan }\end{array}$ & 605 & 609 & 617 & 598 & 614 & 604 & 609 \\
\hline Malaysia & 458 & 456 & 466 & 457 & 451 & 464 & 462 \\
\hline
\end{tabular}

(Source: TIMSS Report 2019, Ministry of Education Malaysia, 2019)

This situation is not so surprising because the practice of science and mathematics education in Malaysia focuses on the mastery of low -level cognitive abilities (Nik Aziz, 2014).

Placing thinking skills as a goal to be achieved will give students ample opportunity to acquire these skills. However, several factors constrain the implementation of thinking skills among teachers themselves. Among them are, the quality of teaching and readiness among teachers contribute to the problem of HOTS implemented in the classroom. Teachers are implementers and are very important in determining the success of educational aspirations in PPPM, 2013-2025 (MOE, 2013). Past studies have proven that the quality of teacher teaching has a major impact on student engagement and achievement in the classroom (Normiati \& Abdul Said, 2018). In fact, teachers 'understanding of mathematics, curriculum and HOTS also contributes to classroom practice, professional development and student achievement (Nor'ain, Zamzana \& Ruslina, 2019).

In fact, mathematics teaching is still procedural in nature that emphasizes algorithms (Munirah, 2015). This is supported by the findings of the Academic Study of Higher Education Leadership (AKEPT), PPPM Preliminary Report, 2012) showed that only $12 \%$ of teaching was delivered at a high standard, while another $38 \%$ were at a satisfactory standard and another $50 \%$ were at an unsatisfactory level. that is, teachers fail to deliver effective teaching, especially in cultivating high -level thinking (MOE, 2013. This gives the impression that the delivery of subjects does not involve students adequately and the way of teaching is more passive and lecture -shaped (Apak \& Taat, 2018) although there are excellent teachers in the Malaysian education system.The subjects presented are more focused on shallow content understanding and do not focus on HOTS.This statistic also shows the big challenges that will be faced as about $60 \%$ of teachers today will continue to teach for another 20 years (KPM, 2013).

Many studies have been done involving critical thinking on almost all subjects such as Islamic Education (Tuan Rahayu, Mohd Aderi, \& Mohd Isa, 2017; Wan Ali Akbar and Nursafra, 2020), Physics (Kaviza, 2020); Mathematics (Kok Pin Wan \& Syed Mohd Hashim, 2018), History (Ariffin \& Yunus, 2017; Siong \& Faridah, 2020) and English (Anida, Zulkifli, Husna Mohd Amir \& Marlini, 2020; Jessica \& Zamri, 2021). Several other studies focus on thinking skills in teaching and learning (Mohd Ashraf, Muhammad Talhah, Aminudin \& Ahmad Marzuki, 2020), issues and challenges of HOTS (Mohd Syaubari, 2020), knowledge and understanding 
of teachers (Nur Aida \& Mohd Aderi, 2014 ), teacher readiness (Rachel Lyne, Mohd Mahzan, Abdul Razaq \& Shakila, 2019; Mazarul, Maizura \& Norazimah, 2020).

However, less research has been done on the construction of modules that are based on thinking skills in mathematics learning. Findings from the needs analysis by researchers in parallel with the study (Nooriza, 2019) found that the KBAT module is the main need raised by teachers. Teachers are of the view that the module can be used as a reference, provide a clearer understanding of HOTS as well as increase teachers' confidence to implement HOTS -based teaching (Mohd Nazri, Ramlee, Nik Azimah \& Rosnidar, 2017; Nur Hawa Hanis \& Ghazali, 2018; Kaviza, 2019). Thus, the need to implement the construction of Thinking-Based Learning (PBP) or Thinking-Based-Learning (M-TBLE) module is a gap in this study conducted.

Vygotsky's (1978) Theory of Social Constructivism underlies this study. This theory states that children's cognitive skills develop systematically, logically and rationally with the help and verbal guidance of others (Mohd Fuad, Marina, Afrah Salwani, Mohd Zain, 2013; Robson, Allen \& Howard, 2020). In this situation, children's cognitive skills result from their external and internal interactions (Norshidah, Manisah \& Khalim, 2018, Norzuraina, 2019) that can directly enhance their understanding.

\section{THINKING-BASED LEARNING}

The concept of Thinking-Based Learning (PBL) was initiated by Robert Swartz and Sandra Parks (Swartz \& Parks, 1994; Swartz, Costa, Beyer, Reagan \& Kallick, 2010). PBP uses an infusion learning approach by incorporating thinking skills as well as developing thinking habits and metacognition into the overall teaching content. Specifically, PBP combines various strategies, methods or techniques that are appropriate to encourage active thinking in students.

PBP in the context of this module involves a direct learning approach by incorporating critical and creative thinking skills through the involvement of students in learning Algebraic Expressions. Pupils are given the opportunity to do various explorations individually or in groups to improve their understanding of the learning content (Rosnee et al., 2021).

To encourage students to structure students' thinking clearly, Robert Swartz and Sandra Parks (Swartz \& Parks, 1994; Swartz, 2010) also introduced the IERT model which consists of four phases namely Introduction (Introducing, I), Engagement (E), reflection. (Reflection, R) and Transfer (T). The closing phase is divided into five phases in all so that students can draw conclusions and self -reflection on the whole learning process.

The effectiveness of the PBP approach covers a wide range of areas of study. Among them are engineering drawings (Norazlinda, 2017); mathematics teaching modules for students with special needs (Nur Jannah, 2018); English, Yue Lin (2018); mathematics (Einav, Morgan \& Tang, 2020 and Science, Engineering, Technology \& Mathematics (STEM), (Hartini, 2020)).

In this regard, this study aims to develop a thinking -based learning module for Form 1 students. This module will also provide a new focus in learning how to deliver lesson content while applying thinking skills.

\section{RESEARCH METHODOLOGY}

Research methodology is important so that the research conducted has appropriate and effective methods in answering research problems (Kumar, 2019). This study uses a survey method to get a clear picture and collect accurate information on the needs of learning modules based on thinking skills for Form 1 Mathematics.

\section{Research design}

The study in developing this M-TBLE module uses Design and Development Research (DDR) (Richey \& Klein, 2014) which consists of needs analysis phase, module design and development phase and module usability evaluation phase. the need aims to know the views of Mathematics teachers on the need to build and develop MTBLE modules.

\section{Study sample}

The study sample consisted of 52 mathematics teachers from across the country by answering a questionnaire using Google Form. The selection of respondents is purposive sampling. The main purpose of this needs analysis is to get feedback from mathematics teachers on whether the construction of the KBAT module is a requirement as well as the proposed form 1 mathematics title. 


\section{Findings}

Table 2. Respondents based on Gender, Teaching Experience and Course Attendance and KBAT Training $(\mathrm{N}=52)$ Respondent Demographics

\begin{tabular}{lcl}
\hline Respondents & Respondents & Percentage (\%) \\
Demographi & 17 & 32.7 \\
\hline Sex & 35 & 67.3 \\
Male & & \\
Female & 37 & 71.2 \\
Major & 12 & 23.1 \\
Mathematics & & 5.7 \\
Mathematics \& & 3 & \\
Sciences & & \\
Others & & \\
Teaching Form & & 48.1 \\
1 Mathematis & 25 & 30.8 \\
$1-10$ years & 16 & 21.1 \\
More yeras & & \\
Moran & 11 & \\
years & & \\
\hline
\end{tabular}

Table 2 shows the feedback of the views of the KBAT module by mathematics teachers from across the country. In conclusion, the findings show that although $3 / 4$ of the respondents have attended the KBAT course, but half of them are still unclear about the teaching involving KBAT.

Table 2. Feedback of teachers' views on the course

\begin{tabular}{llc}
\hline No & \multicolumn{1}{c}{ Items } & $(\%)$ \\
\hline 1. & Have attended the KBAT course The KBAT course & 75.0 \\
2. & was successfully implemented & 45.1 \\
3. & The presentation of the content is clear & 52.1 \\
4. & Adequate distribution materials & 45.1 \\
5. & This course can improve questioning techniques & 44.0 \\
6. & Form 1 Mathematics Module is not provided & 51.9 \\
7. & Accepted modules do not cover all topics & 75.5 \\
\hline
\end{tabular}

Table 3. Form 1 Mathematics Title Feedback by mathematics teachers in Malaysia

\begin{tabular}{llr}
\hline No & \multicolumn{1}{c}{ Topics } & $(\%)$ \\
\hline 1. & Numbers and Ratios & 13.7 \\
2. & Factors and Multiples & 11.5 \\
3. & The square, the square root, & 11.8 \\
& The power of three and the root of the power of & \\
& three & 15.7 \\
4. & Ratios, Rates and Proportions & 23.1 \\
5. & Algebraic expression & 13.5 \\
6. & Linear Equations & 9.6 \\
7. & Linear Inequality & 9.6 \\
8. & Lines and Angles & 7.7 \\
9. & Basic Polygon & 17.3
\end{tabular}




\begin{tabular}{llr}
\hline 10. & Perimeter and Area & 7.7 \\
11. & Set Operation & 11.8 \\
12. & Data Handling & 11.5 \\
13. & Pythagoras theorem &
\end{tabular}

\section{SUMMARY AND SUGGESTION}

The study of the construction of the M-TBLE module that has been discussed will result in 8 units of learning critical and creative thinking skills as a whole. Sidek Module and Development Model (Sidek \& Jamaludin, 2008 ) is used as the basis in the construction process of KBAT module because it has a more comprehensive and detailed structured level and consists of 13 steps and through two stages of development (Sidek \& Jamaludin, 2008). There are two stages of module production, namely, the first stage is the processes of producing module drafts and the second stage is the processes of conducting evaluation of the module. Module construction using the Sidek model can help researchers plan, design, and organize measures systematically. This model is considered complete because it can explain the construction of the module draft so as to test the effectiveness of the module.

In conclusion, there is a need to develop a thinking-based learning module for the title of Form 1 Mathematical Algebraic Expressions. apply thinking skills to encourage active thinking in students.

\section{REFERENCES}

1. Abdul Rashid, Z. (2016). Tahap kesediaan guru dalam aspek pengetahuan dan keperluan latihan berfokuskan aplikasi KBAT (Doctoral dissertation, Universiti Tun Hussein Onn Malaysia).

2. Anida Sarudin, Zulkifli Osman, Husna Faredza, M. R., Mohd Amir, M. Z., \& Idris, M. (2020). Analisis Pelaksanaan Elemen Kemahiran Berfikir Aras Tinggi dalam Kalangan Guru Bahasa Melayu di Sekolah Mennengah Orang Asli. Jurnal Pendidikan Bahasa Melayu, 10(April), 48-63.

3. Apak, J., \& Taat, M. S. (2018). Pengaruh Kesediaan Guru Terhadap Pengurusan Bilik Darjah Abad Ke-21 Abstrak The Influence of Teachers' Readiness Towards 21 st Century Classrom Management Abstract Pengenalan. 3(4), 6-22.

4. AR Abdul Razzaq, KH Tan, MZ Mustafa, N Bokhari. (2017). The Secret to A Successful Homestay Development: Lesson from Miso Walai Homestay (MWH) Kinabatangan Sabah, Malaysia. Pertanika Journal of Social Sciences \& Humanities, 2017.

5. Ariffin, N. A., \& Yunus, F. (2017). Kesediaan Guru Prasekolah Dalam Melaksanakan KBAT Dalam Pengajaran dan Pembelajaran.

6. Ashraf, M., Soh, C., Talhah, M., Jima, A., Hehsan, A., \& Mohamed, A. M. (2020). Penguasaan Kemahiran Berfikir Aras Tinggi (KBAT) dalam Kalangan Guru Pendidikan Islam di Daerah Hulu Langat (Proficiency of Higher Order Thinking Skills (HOTS) Among Islamic Education Teachers in Hulu Langat District). 2(3), 135-149.

7. Ballakrishnan, K., \& Mohamad, M. (2020). Teachers' Teaching Methods in Teaching Higher Order Thinking Skill (HOTS) Comprehension Questions. INTERNATIONAL JOURNAL OF ACADEMIC RESEARCH IN BUSINESS AND SOCIAL SCIENCES, 10(2).

8. Darby, N. M., \& Rashid, A. M. (2017). Critical Thinking Disposition: The Effects of Infusion Approach in Engineering Drawing. Journal of Education and Learning, 6(3), 305-311.

9. Dow, K. E., Jacknis, N., \& Watson, M. W. (2021). A Framework and Resources to Create a Data Analytics-Infused Accounting CurriculumCreate a Data Analytics-Infused Accounting Curriculum. Issues in Accounting Education.

10. Einav, A., Morgan, J. J., \& Tang, B. Q. (2020). Indirect diffusion effect in degenerate reactiondiffusion systems. SIAM Journal on Mathematical Analysis, 52(5), 4314-4361.

11. Ghazali, D., \& Hussin, S. (2018) Metodologi Penyelidikan Dalam Pendidikan. Universiti Malaya.

12. Hartini, S., Mariani, I., \& Sulaeman, N. F. (2020, June). Developing of student worksheets through STEM approach to train critical thinking skills. In Journal of Physics: Conference Series (Vol. 1567, No. 4, p. 042029). IOP Publishing.

13. Hassan, M. N., Mustapha, R., Yusuff, N. A. N., \& Mansor, R. (2017). Pembangunan modul kemahiran berfikir aras tinggi di dalam mata pelajaran sains sekolah rendah: analisis keperluan guru. Sains Humanika, 9(1-5). 
14. Kaviza, M. (2019). Kesan Kaedah Flipped Classroom Dengan Teknik Peer Instruction Terhadap Kemahiran Berfikir Kritis. Kesan Kaedah Flipped Classroom Dengan Teknik Peer Instruction Terhadap Kemahiran Berfikir Kritis, 16(5), 1-12.

15. Kaviza, M. (2020). Motivasi intrinsik dan kemahiran berfikir kritis dalam pembelajaran sejarah berasaskan analisis sumber-sumber teks: Satu kajian faktorial. Jurnal Pendidikan Bitara UPSI, 13(1), 17-26.

16. Kok Pin Wan, \& Ismail, S. M. H. S. (2018). Application Box Out Method In Enhancing The Skills Of Mathematics Problem Solving Questions On Multiplication. Jurnal Penyelidikan Dedikasi Jilid 14, 14, 31-49.

17. KPM. (2013). Lembaga Peperiksaan Malaysia (2013). Pentaksiran kemahiran berfikir aras tinggi. Kementerian Pendidikan Malaysia.

18. Laporan Awal. 2012. Pelan Pembangunan Pendidikan Malaysia 2013-2025. Kementerian Pendidikan Malaysia.

19. Lin, Y. (2018). Core Issues in Developing Critical Thinking Skills. In Springer Nature Singapore Pte Ltd. (Issue Atkinson 1997).

20. Michael O. Martin, Pierre Foy, Dana L. Kelly, and Bethany Fishbein (2019) Report TIMSS 2019 INTERNATIONAL RESULTS IN MATHEMATICS AND SCIENCE https://timssandpirls.bc.edu/timss2019/international-results/wp content/themes/timssandpirls/download-center/TIMSS-2019-International-Results-in-Mathematicsand-Science.pdf

21. Mintzes, J. J., \& Walter, E. M. (Eds.). (2020). Active learning in college science: The case for evidence-based practice. Springer Nature.

22. Mohamad Hanapi, M. H., Komari, M., \& Zakaria, N. (2020). Kesediaan Guru Pendidikan Islam Dalam Pelaksanaan Pembelajaran Abad Ke-21. International Journal of Education and Pedagogy, 2(2), 9-17.

23. Mohamad Zaid Mustafa. (2019) Organizational Commitment Survey: A Confirmatory Factorial Analysis Based On Vocational Colleges Teachers Sample, International Journal Of Engineering And Advanced Technology (Ijeat), Published By : Blue Eyes Intelligence Engineering \& Sciences Publication , 5, 279, ISSN:22498958

24. Mohd Fuad Sam, Marina Majid, Afrah Salwani Jusoh \& Mohd Zain Kosnon (2013). Murid dan alam belajar. Selangor: Penerbit Multimedia Sdn. Bhd.

25. Mohd Syaubari Othman. (2020). ISSUES AND PROBLEMS IN HIGHER ORDER THINKING SKILLS (HOTS) OF TEACHING PRACTICES FROM IBN KHALDUN'S PERSPECTIVE. Malaysian Journal for Islamic Studies, 4(1), 2013-2025.

26. Munirah, G. (2015). Kepekaan Nombor, Numerasi dan Kemahiran Berfikir Aras Tinggi (KBAT) dalam Pendidikan Matematik Sekolah Rendah. Penerbit USM.

27. Nik Azis Nik Pa (2016). Perspektif bersepadu sejagat dalam pendidikan matematik. Universiti Malaya.

28. Nik Azis Nik Pa. (2014). Pengembangan nilai dalam pendidikan matematik dan sains. Kuala Lumpur: Penerbit Universiti Malaya.

29. Nooriza Kassim (2019). Keberkesanan Modul FTI Hots terhadap pengetahuan konseptual dan Prosedural bagi topik pecahan. Tesis Ijazah Doktor Falsafah Tidak Diterbitkan, Bangi: Universiti Kebangsaan Malaysia.

30. Nor Jannah Hassan (2018). Pembangunan dan Pengujian Modul Pengajaran Matematik Tajuk Pecahan untuk Murid Berkeperluan Khas Penglihatan Tahun Empat. Tesis Ijazah Doktor Falsafah Tidak Diterbitkan, Bangi: Universiti Kebangsaan Malaysia

31. Nor'ain Mohd Tajudin, Z. Z., \& Othman, R. A Thinking-Based Learning Module for Enhancing 21 st Century Skills.

32. Norazmi, N. (2020). Effect Size for Model of the Influence of Headmasters Leadership on Teacher Task Load and Teacher Job Satisfaction of Special Education Integration Program. International Journal of Phycpsocial Rehabilitation. Vol. 24, Issue 10, 2020: 2102-2112.

33. Norazmi, N. (2020). Factors for the Task Load of Special Education Integration Program (PPKI) Teachers in Johor. International Journal of Innovative Technology and Exploring Engineering (IJITEE), Volume 9, Issue 3: 2413-2416.

34. Norazmi, N., Zaid, M. \& Abdul Rasid, A. R. (2019). The Practice of Headmasters' Leadership and Its Effect on Job Satisfaction of Special Education Integration Program (PPKI) Teachers in Johor, Malaysia. Universal Journal of Educational Research 7.9 (2019): 2008-2014. DOI: 10.13189/ujer.2019.070923.

35. Norazmi, N., Zaid, M. \& Abdul Rasid, A. R. (2020). Relationship between Headmasters' Leadership, Task Load on Special Education Integration Programme Teachers' Job Satisfaction. Universal Journal of Educational Research 8(8):3398-3405 
36. Norazmi, N., Zaid, M. \& Abdul Rasid, A. R. (2020). Special Education Integration Program (PPKI) Teachers: Task Load and Job Satisfaction. International Journal of Psychosocial Rehabilitation, Vol. 4, Issue 7: 7439-7445.

37. Norzuraina Mohd Nor (2019). Penilaian KIPP dalam Pembelajaran dan Pemudahcara Murid Ketidakupayaan Penglihatan menggunakan Buku Teks Braille Pendidikan Kesenian.Tesis yang belum diterbitkan. Universiti Pendidikan Sultan Idris.

38. Nur Aida Muhammad \& Mohd Aderi Che Noh. 2014. Penerapan Kemahiran Berfikir Aras Tinggi (KBAT) dalam Pengajaran dan Pembelajaran Pendidikan Islam Sekolah Rendah. Prosiding Wacana Pendidikan Islam Siri Ke-10, hlm. 520-541.

39. Nur Hawa Hanis, A., \& Ghazali, D. (2018). Kesediaan guru melaksanakan Kemahiran Berfikir Aras Tinggi dalam pengajaran. Jurnal Kurikulum \& Pengajaran Asia Pasifik, 6(3), 22-31.

40. OECD Economic Surveys Malaysia July 2019 OVERVIEW. http://www.oecd.org/economy/surveys/Malaysia-2019-OECD-economic-survey-overview.pdf.

41. Richey, R. C., \& Klein, J. D. (2014). Design and development research. Mahwah, NJ.

42. Robson, D. A., Allen, M. S., \& Howard, S. J. (2020). Self-regulation in childhood as a predictor of future outcomes: A meta-analytic review. Psychological bulletin, 146(4), 324.

43. Rosnee Ahad, Mohamad Zaid Mustafa, Suhaimi Mohamad, Nur Hanim Saadah Abdullah, Mohd Norazmi Nordin (2021). Work Attitude, Organizational Commitment and Emotional Intelligence of Malaysian Vocational College Teachers. Journal of Technical Education and Training Vol. 13 No. 1 (2021): 15-21.

44. Saputri, A. C. (2019). Improving Students' Critical Thinking Skills in Cell-Metabolism Learning Using Stimulating Higher Order Thinking Skills Model. International Journal of Instruction, 12(1), 327-342.

45. Sidek Mohd Noah \& Jamaludin Ahmad. 2008. Pembinaan Modul: Bagaimana Membina Modul Latihan dan Modul Akademik. Serdang: Penerbit Universiti Putra Malaysia.

46. Siong, Y. K., \& Kutty, F. M. (2020). KEBERKESANAN APLIKASI COGGLE DALAM MENINGKATKAN PENCAPAIAN SEJARAH TINGKATAN ENAM BAGI TOPIK “ PERLUASAN KUASA BARAT DI CHINA ” DI SMK SELIRIK , KAPIT ( The Effectiveness of Coggle Applications To Improve The Performance Of Form 6 History Subject For Topi. Jurnal Dunia Pendidikan, 2(1), 11-30.

47. Swartz, R. J., \& Parks, S. (1994). Infusing the Teaching of Critical and Creative Thinking into Content Instruction: A Lesson Design Handbook for the Elementary Grades. Critical Thinking Press and Software, PO Box 448, Pacific Grove, CA 93950-0448.

48. Swartz, R. J., Costa, A. L., Beyer, B. K., Reagan, R., \& Kallick, B. (2008). Thinking-based learning. Promoting quality student achievement in the 21 st century. New York dan London: Teachers College Press.

49. Swartz, R. J., Costa, A. L., Beyer, B. K., Reagan, R., \& Kallick, B. (2010). Thinking-Based Learning: Promoting Quality Student Achievement in the 21 st Century. Teachers College Press. 1234 Amsterdam Avenue, New York, NY 10027.

50. Swartz, R., \& McGuinness, C. (2014). Developing and assessing thinking skills - Final Report part 1 Literature review and evaluation framework.

51. Tuan Rahayu, T. L., Mohd Aderi, C. N., \& Mohd Isa, H. (2017). Pengetahuan, Sikap dan Kesediaan Murid Terhadap Kemahiran Berfikir Aras Tinggi (KBAT) dalam Mata Pelajaran Tasawwur Islam. Tinta Artikulasi Membina Ummah, 3(1), 15-28.

52. Vygotsky, L.S. (1978). Mind in society: The development of higher psychological processes. Cambridge, MA: Harvard University Press.

53. Wan Ali Akbar Wan Abdullah, Nursafra Mohd Zhaffar, \& Ab. Halim Tamuri. (2020). Aplikasi Kemahiran Berfikir Aras Tinggi (KBAT) dalam Pendidikan Islam. Sains Insani, 5(1), 14-21.

54. Yogesh Hole et al 2019 J. Phys.: Conf. Ser. 1362012121

55. Zaid, M., Norazmi, N. \& Abdul Rasid, A. R. (2020). Headmaster Leadership Effect On Task Load Of Special Education Integration Program Teacher. Humanities \& Social Sciences Reviews, Vol. 8 No. 2 (2020): 451-456.

56. Zaid, M., Norazmi, N. \& Abdul Rasid, A. R. (2020). Regression between Headmaster Leadership, Task Load and Job Satisfaction of Special Education Integration Program Teacher. Universal Journal of Educational Research 8.4 (2020) 1356 - 1362. Doi: 10.13189/ujer.2020.080428.

57. Zaid, M., Norazmi, N. \& Abdul Rasid, A. R. (2020). Special Education Intergration Program in Malaysia: Teachers Task Load as Mediator for the Influence of Headmasters Leadership to Teachers Job Satisfaction. Journal of Critical Reviews 7(12): 2763-2768

58. Zaid, M., Norazmi, N. \& Abdul Rasid, A. R. (2020). Structural Equation Modelling Using AMOS: Confirmatory Factor Analysis for Taskload of Special Education Integration Program Teachers. 
Universal Journal of Educational Research, Vol 8 (Jan, 2020) No 1: 127-133. DOI: 10.13189/ujer.2020.080115.

59. Zaid, M., Norazmi, N. \& Abdul Rasid, A. R., Badaruddin, I. (2021). Vocational College Teachers In Malaysia: Confirmatory Factor Analysisfor Job Attitude. PalArch's Journal of Archaeology of Egypt / Egyptology, 17(9), 5091 - 5098.

60. Zaid, M., Norazmi, N. \& Abdul Rasid, A. R., Badaruddin, I. (2021). Vocational College Teachers In Malaysia: Emotional Intelligence. PalArch's Journal of Archaeology of Egypt / Egyptology, 17(9), 5099 - 5106.

61. Zaid, M., Norazmi, N. \& Abdul Rasid, A. R., Badaruddin, I. (2021). Organizational Commitment of Vocational College Teachers in Malaysia.PalArch's Journal of Archaeology of Egypt / Egyptology, 17(9), 5023-5029.

62. Zaki, F., Ahmad, A., \& Othman, N. (2021). Kompetensi Guru dalam Penerapan Kemahiran Berfikir Aras Tinggi dalam Pengajaran Pendidikan Sejarah. Malaysian Journal of Social Sciences and Humanities (MJSSH), 6(1), 194-205. 